\title{
Triglycerides, free fatty acids and total bilirubin in horses with left ventral colon impaction
}

\author{
Naglaa Gomaa, Gábor Koeller and Gerald F. Schusser \\ Medizinische Tierklinik, Veterinärmedizinische Fakultät, Universität Leipzig, Germany
}

\begin{abstract}
Summary
Colic horses are under stress of pain, anorexia or feed restriction during treatment leading to fat mobilization. The objective of this study is the investigation of fat mobilization in twelve horses with left ventral colon impaction referred to the large animal hospital, University of Leipzig. Serum triglycerides (TG), free fatty acids (FFAs) and total bilirubin (TB) were measured at admission and after impaction resolution. Six healthy horses were used as control in two different protocols. In protocol A the horses were fed twice a day and stabled on straw-bedded boxes without feed over a period of 12 hours (overnight). In protocol B the same horses were transferred into unbedded boxes without feed over a period of 12 hours (overnight). Blood was collected in both protocols at 7.00 a.m. before feeding. In horses with impaction serum FFAs $(830.3 \mu \mathrm{mol} / \mathrm{l}$, median) and TB $(75.9 \mu \mathrm{mol} / \mathrm{l})$ at admission were significantly elevated in comparison with the values of protocol $A$ (129.5 $\mu \mathrm{mol} / \mathrm{l} ; 22.5 \mu \mathrm{mol} / \mathrm{l})$ while serum FFAs did not differ significantly with values in protocol B (395.5 $\mu \mathrm{mol} / \mathrm{l})$. Serum TG $(0.46 \mathrm{mmol} / \mathrm{l})$ of colic horses at admission and of horses in protocol A $(0.46 \mathrm{mmol} / \mathrm{l})$ and $B(0.31 \mathrm{mmol} / \mathrm{l})$ did not differ significantly. These values were still in normal limits. Serum TG and TB of colic horses at impaction resolution ( $1.59 \mathrm{mmol} / \mathrm{l}, \mathrm{P} \leq 0.05 ; 92.9 \mu \mathrm{mol} / \mathrm{l})$ were higher than at admission $(0.46 \mathrm{mmol} / \mathrm{l}, 75.9 \mu \mathrm{mol} / \mathrm{l})$. At impaction resolution FFAs were lower $(553.45 \mu \mathrm{mol} / \mathrm{l})$ than at admission $(830.3 \mu \mathrm{mol} / \mathrm{I})$. Serum triglycerides, FFAs and TB returned to normal in $58.3 \%, 50 \%$ and $25 \%$ of colic horses respectively after impaction resolution. We concluded that the horses with left ventral colon impaction undergo fat mobilization during the period of impaction. This was characterized by mild hypertriglyceridemia and hyperbilirubinemia which are reversible and return to normal after impaction resolution and feeding of the animal. It is recommended that horses with prolonged impaction more than two days and/or increased serum TG $>2.26 \mathrm{mmol} / \mathrm{l}$ should receive partial parenteral nutrition to reduce fat mobilisation and to decrease release of inflammatory cytokines from adipose tissue.
\end{abstract}

Keywords: free fatty acids, triglycerides, bilirubin, left ventral colon impaction, horse

Triglyceride, freie Fettsäuren und Gesamtbilirubin bei Pferden mit Verstopfung der linken ventralen Längslage des großen Kolons

Die Kolik bei Pferden kann aufgrund der Schmerzen, Anorexie oder des Futterentzuges während der Behandlung zur Fettmobilisation führen. Die Fettmobilisation bei zwölf Pferden mit Verstopfung der linken ventralen Längslage des großen Kolons wurde mit Hilfe der Triglyzeride (TG), freien Fettsäuren (FFS) und des Gesamtbilirubins (GB) im Blut charakterisiert. TG, FFS und GB wurden zum Zeitpunkt der Aufnahme und nach der Lösung der Verstopfung analysiert und verglichen. Zum Vergleich wurden sechs gesunde, erwachsene Pferde herangezogen, die zweimal täglich gefüttert wurden und während der Nacht (12 Stunden) ohne Futter waren, jedoch in Boxen mit Stroheinstreu gehalten wurden (Protokoll A). Im Protokoll B wurden die selben Pferde in einem zweiten Durchgang in Boxen ohne Einstreu über Nacht (12 Stunden) gehalten und ebenfalls nicht gefüttert. Die Blutproben wurden bei beiden Gruppen vor der Fütterung am nächsten Tag um 7 Uhr früh genommen. Die FFS $(830,3 \mu \mathrm{mol} / \mathrm{l}$, median) und das GB $(75,9 \mu \mathrm{mol} / \mathrm{l})$ der Pferde mit Verstopfung bei Aufnahme waren signifikant höher als die Werte des Protokolles A $(129,5 \mu \mathrm{mol} / \mathrm{l} ; 22,5 \mu \mathrm{mol} / \mathrm{l})$, wobei die Werte des Protokolles B $(395,5 \mu \mathrm{mol} / \mathrm{l})$ nicht signifikant unterschiedlich waren. Die Werte der TG der Kolikpferde $(0,46 \mathrm{mmol} / \mathrm{l})$, der des Protokolles A $(0,46 \mathrm{mmol} / \mathrm{l})$ und des Protokolles B $(0,31$ $\mathrm{mmol} / \mathrm{I}$ ) differierten nicht signifikant und waren im Normalbereich. Zum Zeitpunkt der Verstopfungslösung waren TG $(1,59 \mathrm{mmol} / \mathrm{I}, \mathrm{P} \leq 0,05)$ and GB $(92,9 \mu \mathrm{mol} / \mathrm{l})$ höher als bei Klinikaufnahme $(0,46 \mathrm{mmol} / \mathrm{l}, 75,9 \mu \mathrm{mol} / \mathrm{l})$. Dagegen die FFS waren niedriger $(553,45 \mu \mathrm{mol} / \mathrm{l})$ zum Zeitpunkt der Verstopfungslösung im Vergleich zur Aufnahme (830,3 $\mu \mathrm{mol} / \mathrm{l})$. Die Werte der TG, FFS und des GB kehrten bei 58,3 \%, 50 \% und $25 \%$ der Kolikpferde nach Verstopfungslösung in den Normalbereich zurück. Zusammenfassend wird festgehalten, dass Pferde mit Verstopfung der Fettmobilisation unterliegen. Die Hypertriglyzeridämie und Hyperbilirubinämie sind nach Fütterung reversibel. Besteht jedoch die Verstopfung mehr als zwei Tage und/oder die TG sind höher als 2,26 mmol/I wird eine partiell parenterale Ernährung empfohlen, damit die Fettmobilisation und die Freisetzung von Entzündungsmediatoren aus dem Fettgewebe reduziert werden.

Schlüsselwörter: Freie Fettsäuren, Triglyceride, Bilirubin, Verstopfung, Pferd

\section{Introduction}

Horses with colic usually have an alteration in normal metabolic rate influenced by pain, anorexia or feed restriction during transportation and treatment. These factors are potential sources of stress in horses, which result in an increase of energy demand and consequently to a fat mobilization from adipose tissue (Edner et al. 2007). During this period of colic, the hormone-sensitive lipase induced by catecholamine con- verts the fat tissue into free fatty acids (FFAs), or nonesterified fatty acids and glycerol. The FFAs are bound to plasma albumin before transportation to the liver. FFAs will be recombined with glycerol to make triglycerides in hepatic cell and secreted into bloodstream as very low density lipoprotein (Jaworski et al 2007).

Three conditions of an increase in plasma lipids are described in equids: hyperlipemia, hyperlipidemia and hypertrigly- 
ceridemia. The severe condition is called hyperlipemia that appears commonly in ponies, donkeys, mules and miniature horses due to negative energy balance. The plasma has a white-to-yellow opacity caused by a high concentration of triglycerides above $5.7 \mathrm{mmol} / \mathrm{I}$ with fatty infiltration of liver and multiple organ systems. Hyperlipidemia is the mild form affecting the horses and characterized by triglycerides concentration below $5.7 \mathrm{mmol} / \mathrm{l}$ and clear plasma without evidence of hepatic dysfunction (Naylor et al 1980, Watson et al 1992, Mogg and Palmer 1995). Hypertriglyceridemia is defined as an elevation of serum triglyceride concentration above the normal range $(<1.13 \mathrm{mmol} / \mathrm{l})$ and is not always associated with evidence of clinical signs (Naylor 1982).

There are many studies on equine hyperlipidemia as a secondary complication associated by withholding of feed and gastrointestinal diseases in ponies and miniature horses (Schotman and Wagenaar 1969, Bartley 1970, Weik and Altmann 1971, Morris et al. 1972, Freestone et al. 1991, Mogg and Palmer 1995). However, Milne et al 1990 described that the fat mobilization in horses with colic does not reach the level of hyperlipemia. Dunkel and McKenzie 2003 reported a condition of sever hypertriglyceridemia in adult horses with serum triglycerides concentration $>5.7 \mathrm{mmol} / \mathrm{l}$ without plasma opacity or evidence of clinical effect. The most common primary diseases in these horses were enteritis and colitis.

The increase of FFAs concentration in plasma induces indirectly mitochondrial reactive oxygen species (ROS) (Ceriello and Motz 2004). ROS has a pro-inflammatory effect and increases pro-inflammatory cytokines (Tripathy et al. 2003). Tumor necrosis factor (TNF- $\alpha$ ), one of pro-inflammatory cytokines that suppresses lipoprotein lipase synthesis in adipocytes and impairs the insulin action and consequently the concentration of triglycerides in plasma are increased (Grunfeld and Feingold 1991, Nakamura 1998). Therefore, there is an interrelationship among fat mobilization, insulin resistance and inflammatory process in horses (Vick et al. 2007).

The present study aims to investigate the fat mobilisation characterized by measuring of serum FFAs, triglycerides and total bilirubin in horses with left ventral colon impaction which are under feed restriction during the period of treatment.

\section{Materials and Methods}

Medical records of 39 horses with left ventral colon impaction were reviewed. These horses were presented to the hospital of large animal medicine, Faculty of Veterinary Medicine, University of Leipzig between January 2005 and February 2008. Signalment, clinical signs, physical examination findings, duration of clinical signs, the treatment's duration and results of laboratory analysis (cell blood count, total protein, serum triglycerides, FFAs, total bilirubin) were obtained from the medical records at admission and after resolving of impaction. The diagnosis of impaction in the left ventral large colon and resolution based on rectal palpation.

Six apparently healthy adult Warmblood horses are used as control horses with two different protocols: Protocol A included horses which were fed two times a day $(1,5 \mathrm{~kg}$ hay/100 kg b.w. and $1 \mathrm{~kg}$ carrots per day) and stabled on straw-bedded boxes. Next day after feeding, all horses were transferred into unbedded boxes without feeding but with free access to water for 12 hours during the night (protocol B). In protocol $A$, venous blood samples were collected from jugular vein at 7:00 a.m. before feeding. The next samples were taken after $2,3,4$, and 5 hours of feeding. In protocol B, venous blood samples were collected at 7:00 a.m. in the next day. After standing 30 minutes at room temperature, the blood samples were centrifuged at $450 \mathrm{~g}$ for $10 \mathrm{~min}$. The serum samples were collected and kept at $-20^{\circ} \mathrm{C}$ until they were analyzed. Automatic analyzer (Hitachi 912, Boehringer Mannheim) was used for measuring triglycerides, FFAs and total biliubin in serum samples.

\section{Statistical analysis}

The data were analyzed using the statistical computer programme SPSS 15 (SPSS-software GmbH, Munich). Descriptive statistical analysis (mean $\pm \mathrm{sd}$, median, minimum and maximum) of clinical findings, concentrations of serum triglycerides, FFAs and total bilirubin were calculated in horses with impaction at admission and after resolve of impaction as well as in control horses. Paired samples T test was used to compare within control horses in protocol A and B. Wilcoxon Signed Rank test was used to compare between horses with impaction at admission and after treatment. Mann-Whitney U- Test was used for comparison between protocol A before feeding and horses with impaction at admission and after resolving of impaction. Nonparametric correlation between triglycerides, FFAs and total bilirubin at admission and after resolving of impaction was measured using Spearman's test. Significance was established at a level of $P \leq 0.05$.

\section{Results}

Only 12/39 horses with clinical pathological findings of triglycerides, FFAs and total bilirubin were found at admission and after resolution of the impaction. Eight mares, three geldings and one stallion of various breeds (nine Warmbloods, two Thoroughbreds, one German riding pony) were 3-22 years old (median 7 years). At admission heart, respiratory rates and rectal temperatures in these horses were $46.5 \pm 6.9 / \mathrm{min}, 18.5 \pm 4.9 / \mathrm{min}$ and $37.7 \pm 0.6^{\circ} \mathrm{C}$ respectively. $10 / 12$ horses had normal mucous membranes and only two horses had congested and mild icteric mucous membranes. All horses had reduced intestinal sounds on the left abdominal region. Colic duration prior to referral ranged from 4 hours to 2 days, (median 1 day). All horses recovered from impaction within 12 hours to 6 days, (median 2 days). During treatment the horses were muzzled, stabled on woodchip bedding, withheld from feed but had free access to water. Pain was controlled by using $20 \mathrm{mg}$ Metamizol/kg b.w. or $1.1 \mathrm{mg}$ Flunixin meglumine/kg b.w. two times a day i.v. The laxative sodium sulphate solution (140 g/10 L water/500 kg b.w.) was administered via nasogastric tube daily.

The laboratory results of leucocytes, erythrocytes and total protein were $6.9 \pm 1.3 \mathrm{G} / \mathrm{l}, 6.6 \pm 1.3 \mathrm{~T} / \mathrm{l}, 65.3 \pm 0.6 \mathrm{~g} / \mathrm{l}$ respectively in horses with left ventral colon impaction at admission, which were within normal range. 
Table 1 Protocol A: Six clinically healthy horses stabled overnight on straw-bedded boxes without feed for 12 hours. Triglycerides (TG), free fatty acids (FFAs) and total bilirubin were measured at 7.00 a.m before feeding and 4 times hourly. Using median, minimum (min.), and maximum (max.). Significant differences $(P \leq 0.05)$ are signed with stars. (a) Naylor 1983, (b) Schäfer 1999

\begin{tabular}{lccc}
\hline & $\begin{array}{c}\text { TG (mmol/l) } \\
\text { median }(\text { min-max) }\end{array}$ & $\begin{array}{c}\text { FFAs }(\mu \mathrm{mol} / \mathrm{I}) \\
\text { median }(\min -\mathrm{max})\end{array}$ & $\begin{array}{c}\text { Total bilirubin }(\mu \mathrm{mol} / \mathrm{I}) \\
\text { median }(\mathrm{mini}-\mathrm{max})\end{array}$ \\
\hline Reference ranges & $<1.13 \mathrm{mmol} / \mathrm{l}(\mathrm{a})$ & $100-300 \mu \mathrm{mol} / \mathrm{l}(\mathrm{b})$ & $<47.8 \mu \mathrm{mol} / \mathrm{l}(\mathrm{b})$ \\
Blood was collected at 7.00 a.m. before feeding & $0.45(0.30-0.57)$ & $129.50^{*}(67.5-170)$ & $22.55(17.13-34.25)$ \\
2 hr. after feeding & $0.47(0.26-0.69)$ & $65(49-109)$ & $23(13.6-39)$ \\
3 hr. after feeding & $0.42(0.24-0.71)$ & $67.5(43-87)$ & $22(14.4-38)$ \\
4 hr. after feeding & $0.43(0.28-0.76)$ & $56(46-157)$ & $22.5(14.5-41)$ \\
5 hr. after feeding & $0.46(0.36-0.64)$ & $47^{*}(42-77.25)$ & $21.80(17.13-34.25)$ \\
\hline
\end{tabular}

Table 2 Protocol B: Six clinically healthy horses stabled overnight on unbedded boxes without feed for 12 hours. Triglycerides (TG), free fatty acids (FFAs) and total bilirubin were measured at 7.00 a.m. Using median, minimum (min.), and maximum (max.).

\begin{tabular}{lccc}
\hline & $\begin{array}{c}\text { TG }(\mathrm{mmol} / \mathrm{I}) \\
\text { median }(\min -\mathrm{max})\end{array}$ & $\begin{array}{c}\text { FFAs }(\mu \mathrm{mol} / \mathrm{I}) \\
\text { median }(\min -\mathrm{max})\end{array}$ & $\begin{array}{c}\text { Total bilirubin }(\mu \mathrm{mol} / \mathrm{I}) \\
\text { median }(\min -\mathrm{max})\end{array}$ \\
\hline Blood was collected at 7.00 a.m. before feeding & $0.31(0.23-0.38)$ & $395.50(292.75-520)$ & $27.15(21.38-29.93)$ \\
\hline
\end{tabular}

In protocol A serum FFA concentration decreased significantly 5 hours after feeding compared to the value before feeding. There were no changes of serum triglycerides and total bilirubin concentrations (table 1). In protocol B only FFAs concentration was significantly higher in comparison to the value in protocol A before feeding (table 2). At admission serum FFAs (12/12 horses) and total bilirubin (11/12 horses) concentrations were significantly elevated while serum triglyceride did not differ significantly in comparison with normal horses in protocol A before feeding. Serum triglycerides measured after impaction resolution were significantly higher compared with values at admission. Serum FFAs and total bilirubin did not differ significantly at admission and after impaction resolution (table 3 ).

$7 / 12$ and $6 / 12$ horses with impaction had normal values of triglycerides and FFAs respectively after resolving impaction. The decrease of FFAs and triglycerides correlated significantly $(r=0.87)$. Total bilirubin was still increased in $9 / 12$ horses when the impaction was resolved. All colic horses were discharged one to two days (median 2 days) after impaction resolution.

\section{Discussion}

Disturbances of lipid metabolism that result in accumulation of serum triglycerides and FFAs associated with hyperbilirubinemia are common in equine species. Severe hypertriglyceridemia (6.17 - $18.29 \mathrm{mmol} / \mathrm{l})$ occurs commonly in very sick inappetent horses (Dunkel and McKenzie 2003). Based on the normal leucocytes counts horses of our study had left ventral colon impaction but had no systemic inflammation. These horses had only a mild elevation of serum triglyceride concentration $(1.59 \mathrm{mmol} / \mathrm{l})$ at the time of impaction resolution. In comparison with reported reference range $(<1.13 \mathrm{mmol} / \mathrm{l})$ the measured triglyceride concentration of these colic horses was slightly out of range (Naylor et al 1980). This elevated triglyceride concentration could be caused by overwhelming of clearance mechanisms (Hughes et al. 2004). There was a moderate elevation of serum FFAs measured at admission and after impaction resolution. The reason of the elevation of triglycerides and FFAs could be the increase of catecholamine and cortisol in response to anorexia and pain in colic horses (Hinchcliff et al. 2005). Cortisol and catecholamine stimulate hormone sensitive lipase and reduce the efficiency of circulating insulin (Jaworski et al 2007). The indirect bilirubin could be competed by higher concentrated FFAs in the serum on hepatic carrier-mediator leading to an increase of serum total bilirubin (Gronwall and Mia 1972). Based on this pathophysiological mechanism the horses with impaction had increased total bilirubin at admission and after impaction resolution.

The normal serum triglyceride and elevated FFA concentrations measured at admission in horses with a colic duration of one day (median) could be comparable to the values found in unfed horses stabled without bedding (protocol B). In contrast unfed horses with bedding had lower values of FFAs (protocol A). These horses were able to have a straw intake during the night. The lower digestible energy of straw could stabilize the fat metabolism to prevent the increase of FFAs in the serum.

Table 3 Triglycerides (TG), free fatty acids (FFAs) and total bilirubin of 12 horses with left ventral colon impaction at admission and after impaction resolution. Significant differences $(P \leq 0.05)$ are signed with stars.

\begin{tabular}{|c|c|c|c|c|c|c|}
\hline & \multicolumn{3}{|c|}{ at admission } & \multicolumn{3}{|c|}{ after impaction resolution } \\
\hline & $\begin{array}{c}\mathrm{TG} \\
\mathrm{mmol} / \mathrm{l}\end{array}$ & $\begin{array}{l}\text { FFAs } \\
\mu \mathrm{mol} / / \mathrm{l}\end{array}$ & $\begin{array}{c}\text { Total bilirubin } \\
\mu \mathrm{mol} / /\end{array}$ & $\begin{array}{c}\mathrm{TG} \\
\mathrm{mmol} / \mathrm{I}\end{array}$ & $\begin{array}{c}\mathrm{FFAs} \\
\mu \mathrm{mol} / \mathrm{l}\end{array}$ & $\begin{array}{c}\text { Total bilirubin } \\
\mu \mathrm{mol} / \mathrm{l}\end{array}$ \\
\hline median & $0.46^{*}$ & 830.3 & 75.94 & $1.59^{*}$ & 553.45 & 92.97 \\
\hline $\min$. & 0.14 & 424 & 37.10 & 0.20 & 34 & 32 \\
\hline $\max$. & 1.25 & 1441 & 125.10 & 3.83 & 1638 & 165 \\
\hline
\end{tabular}


The elevated level of FFAs might be attributed by inappetence in horses which suffered from impaction. These colic horses had neither feed nor straw-bedding intake before admission. Gronwall and Mia 1972 reported that serum triglycerides increased only after 40 hours of feed deprivation while total bilirubin rose after 18 hours of fasting. At admission the normal level of triglycerides in our colic horses could be associated with a shorter period of inappetence during colic. On the other hand the total bilirubin in 11/12 horses with impaction was elevated because inappetence during colic lasted longer than 18 hours. This is similar to hyperbilirubinemia in fasting horses described by Engelking 1993.

After impaction resolution serum triglycerides and FFAs of $58.3 \%$ and $50 \%$ of horses returned to normal ranges. While only $25 \%$ of colic horses had normal values of total bilirubin. The FFA concentration decreased $40 \%$ after feeding started (Gronwall and Engelking 1982). But triglycerides and total bilirubin return to normal values in fed horses within 2 to 7 days (Dunkel and McKenzie 2003).

We conclude that horses with left ventral colon impaction were exposed to fat mobilisation by inappetence or withholding of feed and pain during colic and treatment period. It is characterised by mild increase of triglycerides, FFAs and total bilirubin. This mild hypertriglyceridemia is reversible after feeding.

We recommend that horses with impaction and/or increased serum triglyceride level $>2.26 \mathrm{mmol} / \mathrm{I}$ (Naylor et al 1980) during a prolonged treatment period more than two days should get partial parenteral nutrition. For example: mixture of $4 \mathrm{~L}$ glucose solution $40 \%$ and $6 \mathrm{~L}$ saline solution i.v. daily for a horse with $500 \mathrm{~kg}$ b.w. (Schusser 1996). The parenteral nutrition reduces lipolysis which could enhance the release of pro-inflammatory cytokines from adipose tissue (Vick et al. 2007). Further studies are needed on fat mobilisation and releasing of inflammatory cytokines in colic horses with laminitis, thrombophlebitis, paralytic ileus, peritonitis and wound healing problems of surgical cases.

\section{References}

Bartley J. C. (1970) Equine lipemia. In: Clinical Biochemistry of Domestic Animals. Academic Press, New York 88-92

Cerirlo A. and Motz E. (2004) Is oxidative stress the pathogenic mechanism underlying insulin resistance, diabetes and cardiovascular disease? The common soil hypothesis revisited. Arteriosclerosis, Thrombosis and vascular biopsy 24, 816-824

Dunkel B. and Mckenzie H. C (2003) Sever hypertriglyceridemia in clinically ill horses: diagnosis, treatment and outcome. Equine Vet. J. $35,590-595$

Edner H. A., Nyman C. G. and Essén-Gustavsson B. (2007) Metabolism before, during and after anaesthesia in colic and healthy horses. Acta Vet. Scand. 49, 34-50

Engelking L. R (1993) Equine fasting hyperbilirubinemia. Advances in veterinary science and comparative medicine. 37, 115-125

Freestone F. J, Wolfsheimer J. K., Ford B. R., Church G. and Bessin R. (1991) Triglyceride, Insulin, and Cortisol Responses of ponies to fasting and Dexamethasone Adminstration. J. Vet. Int. Med. 5, 15-22
Gronwall R. and Engelking R. L. (1982) Effect of glucose administration on equine fasting hyperbilirubinemia. Am. J. Vet. Res. 43, 801-803

Gronwall R. and Mia A. S. (1972) Fasting hyperbilirubinemia in horses. Digestive diseases and Sciences 17, 473-476

Grunfeld C. and Feingold K. R. (1991) Tumor necrosis factor, cytokines, and the hyperlipidemia of infection. Trends Endocrinol. Metabol. 2, 213-219

Hughes K .J, Hodgeson D. R. and Dart A. J(2004) Equine hyperlipaemia: a review. Aust. Vet. J. 82, 136-142

Hinchcliff K. W., Rush B. R. and Farris J. W. (2005) Evaluation of plasma catecholamine and serum cortisol concentrations in horses with colic. J. Am. Vet. Med. Assoc. 227, 276-80

Jaworski K., Sarkadi-Nagy E., Duncan R., Ahmadain M. and Sul S. H. (2007) Hormonal regulation of lipolysis in Adipose Tissue. Am. J. physiol. Gastrointest. liver physiol. 293, 1-4

Milne M. E., Doxey L. D. and Gilmour S. J. (1990) Serum lipids and lipoproteins in equine colic and grass sickness. Res. Vet. Sci. 48, 170-174

Mogg T. D. and Palmer J. E. (1995) Hyperlipidemia, hyperlipemia, and hepatic lipidosis in American miniature horses: 23 cases (1990-1994). J. Am.Vet. Med. Assoc. 207, 604-607

Morris D. M., Zilversmit B. D. and Hintz F. H. (1972) Hyperlipoproteinemia in fasting ponies. J. lipid Res. 13, 383-389

Nakamura Y. (1998) Alterations of serum lipid, lipoprotein and inflammatory cytokine profiles of rabbits infected with Trypanosoma brucei. Vet. Parasitol. 80, 117-25

Naylor J. M. (1982) Hyperlipemia in horse, ponies and donkeys. Comp. Cont. Educ. Pract. Vet. 4, 321-326

Naylor J. M., Kronfeld D. S. and Acland H. (1980) Hyperlipidemia in horses: effects of undernutrition and disease. Am. J. Vet. Res. 41, 899-905

Schäfer M. (1999) Hämatologische und biochemische Parameter des gesunden Pferdes. In: Handbuch Pferdepraxis. Dietz O. and Huskamp B., Ed, Ferdinand Enke Verlag, Stuttgart, pp. 4

Schotman A. J. H. and Wagenaar G. (1969) Hyperlipemia in ponies. Zentralbl. Veterinaermed. A 16, 1-7

Schusser G. F (1996) Partielle und total parentale Ernährung: Indiktionen und Praxisrelevanz beim Pferd. Praktischen Tierarzt, Collegium Veterinarium 26, 62-63

Tripathy D., Mohanty P., Dhindsa S., Syed T., Ghanim H., Aljada A. and Dandona P. (2003) Evaluation of free fatty acids induces inflammation and impairs vascular reactivity in healthy subjects. Diabetes 52, 2882-2887

Vick M. M., Adams A. A., Murphy A. B., Sessions R. D., Horohover W. D., Cook F. R., Shelton J. B. and Fitzgerald P. B. (2007) Relationships among inflammatory cytokines, obesity, and insulin sensitivity in the horse. J. Anim. Sci. 85, 1144-1155

Watson T. D. G, Murphy D. and Love S. (1992) Equine hyperlipemia in the United Kingdom: clinical features and blood biochemistry of 18 cases. Vet. Rec. 131, 48-51

Weik M. and Altmann H. J. (1971) Das verhalten einiger Blutlipide während des Hungerns beim Pferd. Zentralbl. Veterinaerimed. A $18,131-138$

Prof. Dr. Dipl. ECEIM Gerald Fritz Schusser

Clinic of large animal internal medicine

University of Leipzig

An den Tierkliniken 11

04103Leipzig

schusser@vetmed.uni-leipzig.de 